Kohl: a Journal for Body and Gender Research

Vol. 6, No. 3 (Winter 2020)

\title{
Un/Disclosing Queerness in Akram Zaatari's Al-ilka al-hamra (2000)
}

\section{Elia Eliev}

\begin{abstract}
:
My use of queer in this article takes form as a range of acts, identities, expressions, desires, tendencies, affectivities, and sentiments that divert from the practices of heteronormativity in continuously changing and imaginative ways. In the of analysis Al-ilka al-hamra, the aim is not to locate an "authentic" queer subject, which would ultimately fall into a colonialist and liberatory framework, but rather to outline nonhierarchical and denormalizing ways of thinking and organizing gender and sexuality.
\end{abstract}


In Lebanon, unconcealed depictions of homosexuality in visual media are forbidden by the state from making their way to mainstream audiences. Censorship controls over creative works fall under the jurisdiction of the Directorate General of General Security - an office commissioned to monitor and prejudge works to be made, filter works in circulation from public access, and respond to any application for filming and screening permits (Saghieh et al. 2010). According to the General Security, artworks, films, theater plays, and publications revolving around taboo topics, such as religion, politics, and sex, are subjected to censorship as they could be considered "inappropriate and unfavorable" to the country's interest, which could provoke "unrest," "disorderly conduct," and "arouse certain sensitivities" (Saghieh et al. 2010, 23, 31 \& 49). In their censorship practice, the General Security holds discretionary powers in their assessment of works to be accepted or rejected for public viewing. As stated by Saghieh et al., the censorship evaluation criteria used by the General Security are "broad to the point that anything can be deemed censurable" $(2010,80)$. To circumvent strict regulations and laws around censorship, contemporary artists and filmmakers from the Arab world and the Middle East lean towards the use of strategies such as "melodramatic devices," "coding," and "subtext" (Hassan 2010, 19), in addition to "visual metaphors," "poeticism and self-effacement" (Fitzpatrick 2015, 184) to address taboo subjects such as sex and sexuality without repercussion from the state censorship board.

Akram Zaatari (born 1966 in Saida, Lebanon) is one artist who addresses taboo subjects in his artwork with a clever nod to Lebanon's censure. While Zaatari is most known for his work on themes of war, memory, and displacement, he has also developed a compelling body of artworks conveying subtle yet powerful messages and narratives around male sexuality and same-sex intimacy, as well as the violent oppressive effects of patriarchy and heteronormativity. ${ }^{1}$ For this article, I analyze Akram Zaatari Al-ilka al-hamra (Red Chewing Gum) (2000) - a non-heteronormative snapshot that recounts a sensual love-story among three young men in an obscure alleyway in Beirut at the start of the Lebanese Civil War. My aim is to explore the visual strategies employed by Zaatari to depict and discuss the various ways in which the protagonists negotiate their sexuality in Beirut, where acts of homoantagonism ${ }^{2}$ are still widespread. As further explored in the article, these strategies include: the omnipresent use of the color red, two distinct moments where the video freezes, moments of hesitation between the characters, and finally, optical distortions.

It is critical to briefly review the concept of queer in order to better understand its use. While queer can function as a sociopolitical unifying umbrella for members of the Lesbian, Gay, Bisexual, Transgender (LGBT) community, it can also refer to more a complex meaning. ${ }^{3}$ As remarked by queer theorist Lee Edelman, "queerness can never define an identity; it can only ever disturb one" $(2004,17)$. In this sense, while "queer

\footnotetext{
${ }^{1}$ Some of his video artworks that explore such topics include: Majnounak (1997), Red Chewing Gum (2000), Her + Him VAN LEO (2001), How I Love you (2001), and Tomorrow Everything Will Be Alright (2010).

2 I adopt the term "homoantagonism" from the Anti-Violence Project defined as: "Active hostility or opposition towards people whose sexuality is not heteronormative. This is often based on the assumption that monogamous relationships between one man and one woman is the traditional, superior, and only legitimate form of sexuality. The language has shifted from the use of "phobia" (as in homophobia), to the use of antagonism to better encompass the violence that is perpetrated." https://www.antiviolenceproject.org/glossary/\#homoantagonism

${ }^{3}$ For an introduction to queer theory, see Annamaria Jagose's Queer Theory: An Introduction (1996), and Nikki Sullivan's A Critical Introduction to Queer Theory (2003).
} 
can represent a noun (' $x$ ' is queer), it can also represent an adjective (e.g., queer ' $x$ '), [a] verb (e.g., to queer 'x,' queering ' $x$ ') and [an] adverb (e.g., 'x-ing' queerly)" (Harper et al. 1990, 30). As noted by Annamarie Jagose, it is "a concept that prominently insists on the radical unknowability of its future formations," that maintains a "strategically open-ended relational character" $(2009,158)$. Or as pointed out by Donald Hall, queer theory should be understood in the plural: "there is no 'queer theory' in the singular, only many different voices and sometimes overlapping, sometimes divergent perspectives that can be loosely call 'queer theories'" $(2003,5)$. My use of queer in this article takes form as a range of acts, identities, expressions, desires, tendencies, affectivities, and sentiments that divert from the practices of heteronormativity in continuously changing and imaginative ways. In the analysis of Al-ilka al-hamra, the aim is not to locate an "authentic" queer subject, which would ultimately fall into a colonialist and liberatory framework, but rather to outline nonhierarchical and denormalizing ways of thinking and organizing gender and sexuality.

\section{Al-ilka al-hamra (2000)}

Zaatari's Al-ilka al-hamra (Red Chewing Gum) (2000) is a ten-minute-long video, narrated as a love letter, that tells the story of the separation of two young male lovers during the early rumblings of the Lebanese Civil War. The video's narrator, speaking in Arabic with English subtitles, recounts how he and his male lover ended up alone together in some dark alleyway fifteen years earlier in Hamra, a formerly booming commercial center in Beirut. There, the couple follow and closely observed a young street vendor chewing pieces of gum non-stop. Throughout the video, the couple starts to develop a particular interest in this vendor. The video is mostly comprised of scenes filmed in a studio setting, while intertwined with what seems to be actual raw video footage taken by the narrator's lover.

In the opening scene a young disheveled man is seen sitting on the pavement in a dark alleyway. While chewing on a piece of gum, he looks directly at the camera, expressionless and silent. The scene abruptly cuts to the lively street of Hamra, which seems to be busy as usual with pedestrians and vehicles circulating, thus suggesting that the Civil War has yet to occur. Suddenly, the scream of a siren is heard at a distance, piercing the air, to possibly signal an attack. As explained by the narrator, both he and his lover, against the sound of gunshots, seek refuge in a dark alleyway where they encounter a young street vendor, who is casually sitting on the side of the sidewalk as if everything around him had stopped in time. The narrator and his lover observe the young man engaging in a curious ritual. He is seen compulsively masticating pieces of Chiclets $^{\mathrm{TM}}$ - a popular candy-coated chewing gum brand that is known for its yellow packaging box. Chewing one piece of white gum after another, he sucks and swallows all the sugary juice, leaving them flavorless and shapeless. He spits them out in a little box repeatedly uttering: "there's no sugar left" (00:55, 02:47, and 3:46 $\mathrm{min})$. Among the pile of white chewed gum, a chewed single red one catches the eye of the narrator's lover. The vendor silently glances at both men discreetly acknowledging their presence. As soon as he looks away, the narrator's lover picks up the red gum with his middle finger and challenges his partner to chew the gum. 
Eventually, both men take part in a peculiar activity: the lover slowly opens his mouth and begins to suck the gum with his middle finger leaving a red stain on his tongue. Such an act could be seen as sexually suggestive given its sexual undertones that are intended to perhaps arouse the couple. This scene is repeatedly referenced by the narrator who verbally reiterates it in the video, each time revealing new information. It is accompanied by the well-known song by Egyptian multi-award-winning singer Amr Diab "Tamally Maak" (2000), ("Always with you"). The song's original rendition is about an inseparable love and bond of a heterosexual couple. In Al-ilka al-hamra, the narrator's lover is seen and heard singing acapella the song's chorus:

I feel I'm always with you

Even when you are away, your love survives inside of me Makes me feel always with you

Always in my mind and heart Missing you, even when next to you (01:08- 1:25 min).

The chorus is sung four times in different parts of the video. It first appears at the beginning of the video when the narrator and his lover first encounter the vendor boy. Next, it appears after the three men are in the alley way, hiding from the stray bullets. And finally, it appears twice at the end of the video when the narrator seems to have become separated from his lover. Near the end, the narrator is still unsure as to why his lover had so much pleasure chewing the red gum. Yet, he admits to finding pleasure watching his partner engage in such an erotic act in front of the vendor. The video concludes in an unpromising manner: we learn that the narrator and his lover are separated perhaps because of the city's segregated sectarian lines. Without giving the viewer too much detail, the narrator brings up his move out of Hamra to relocate to Ashrafieh, a predominantly Christian neighborhood in East Beirut, while his lover presumably stayed in Hamra, a Muslim district in West Beirut (9:00 min). The narrator indicates that their separation resulted in them never recoupling and ultimately losing contact.

We are told by the narrator that his lover had videotaped parts of the evening including their encounter with the young vendor. In a studio (possibly his lover's space), a video of a deserted street is projected on the wall, where the narrator reminisces about the eventful night through the video footage likely left behind by his lover. The images on the old fifteen-year-old VHS tapes have faded with time, leaving the narrator to rely on his sensorial and olfactory memories. Thus, the obscure events remain in the narrator's consciousness and manifest through the chorus of "Tamally Maak," the sounds of gunshots, the smell of car fumes, and the feeling of hands touching (9:18 - 9:32 min). The video concludes with an impassioned address by the narrator towards his lost ex-lover: "He [the young vendor] sends you his regards, I hope you remember him?" (10:07 $\min )$.

\section{Hamra - between past and present}


Al-ilka al-hamra was Zaatari's contribution to the Hamra Street Project (2000) in Beirut, an art initiative curated by Christine Tohmé. The project reflected on both the historical and present image of Hamra, Beirut's busiest and most renowned cosmopolitan causeway. In Arabic, the word hamra means "red." While some attribute the name of the street to the auburn color of the soil from the farms of the Ras Beirut neighborhood, others have suggested it was named because of the red window shutters of the Red House - one of the last standing traditional villas in Beirut (Merabet 2014; El Chamaa 2016). Prior to the Lebanese Civil War, Hamra Street was the cultural epicenter of Beirut. During the Civil War, the Hamra District became a well-known hangout for queer-identified men who could meet clandestinely in the narrowing-streets or in the street-level cafés near the Horseshoe Building (Merabet 2014, 84).

Within the video, the color red is important to the visual storytelling as it allows the artist to convey certain moods and stir certain reactions and emotions in nonverbal ways, all of which engage the audience's attention. Not only is the color referenced in the title, but it is also amplified and recurrent throughout the video in terms of effects and lighting. In the opening scene, one can only see a reddened and distorted image of what seems to be the surroundings of Hamra. As the camera pans to the left, the first image moves with the frame, to reveal an undistorted, untinted, and clearly defined street. The video frame is divided by the convex edge of the first image - we realize that the first image was a reflection in a shiny red sphere-like object. The camera zooms out and shows cars and pedestrians. In effect, Zaatari destabilizes our perception by convincing us that the reflection in the red object is the whole image, before revealing that that image is merely a reflection within the larger, "real" world. This red sphere is recurrent throughout the video and is used each time the narrator is reminiscing about his past, thus inscribing the object as a representation of "another time." In this context, "another time" is not necessarily the past, but rather something in between past and present. The narrator is recreating fifteen-year-old memories in the present, perhaps now physically walking around in these spaces where his queer experiences took place, which have been previously closed off because of his sectarian affiliation. This is one instance in which Zaatari blurs our understanding of time.

Additionally, the visual distortion which rounds and reddens the image as reflected in the sphere hints at the narrator's conception of the physical space he once knew. In the course of and following the fifteen years of Civil War, the neighborhood of Hamra was destroyed, rebuilt, and gentrified. This actual distortion may be what is represented by the visual distortion of the reflection in the red sphere. The narrator is trying to describe his Hamra, that he knew. He wants to share how different it was, through the dichotomy between the red sphere and the clearly demarcated image of a modern Hamra. He seems to be still searching for that space that brought him pleasure. Here, the omnipresent use of the color red appears to be representative of two distinct periods in time (and to some extent is utilized to show the protagonists living in two parallel worlds). This seems purposefully done so as to differentiate the story strands in the video that are non-linear. For instance, the narrator's recurring flashbacks are composed non-chronologically and therefore creating multiple unresolved narratives. Throughout the video, what I am calling the "dark-shadowy scenes" are interspersed with red scenes, which are created by filming the reflection of the red metallic sphere object. The dark-shadowy scenes seem more to represent the present post-war period, whereas the red colored scene is suggestive of the reminiscing of the past. 
As viewers, we are immersed within the men's alternative universe. Thus, the color metaphorically and literally tints the narrator's view and experience of the city. The narrator's vision (as seen in the distorted effect of the red sphere) seems to create an atmosphere of melancholy, which can be said to be caused by his separation of his lover. Did his lover die as a result of the Civil War? How did they lose touch? Was the lover living a double life? Did he get married? What was their relationship? Was it a queer amorous one, a fling, or simply a friendship? Here, Al-ilka al-hamra may be considered to be set in a "queer time" in which the protagonists (who are already non-normative) are located outside of the "temporal frames of bourgeois reproduction and family, longevity, risk/safety and inheritance" (Halberstam 2005, 6).

Within the video, Zaatari invites us to engage with this story from the narrator's perspective. To that end, he employs a particular method that leads to a degree of theatricality: the narrator's verbal recounting of the past events is staged and filmed in a studio setting. This includes his dialogue with his lover, which is filmed against a background of video-projections of Hamra Street. Furthermore, the dialogue is reconstituted and played by two actors. Each of these elements combine to form a construction of time and memory in a theatrical way - it is as if, rather than film a nostalgic love story, Zaatari is filming the process of its reconstruction. Such an approach simultaneously displaces our typical position as an audience, and draws us into a much more intimate space - one within the narrator's mind, which is grieving, and struggling to remember - leading to the breakdown of linear time, thus repeating fragments of the narrative, each time adding more detail. In this space, there are also fewer social filters - leading to uncomfortable moments where the actors gaze directly into the camera, and where the narrator speaks about unusual shared moments and acts between men. Such a space can be described within a queer temporality - where social norms fade, and where we are invited to adopt the narrator's gaze in addition to and in dialogue with our own.

\section{Queer Acts: Fellatio \& Exchange of Money}

In Al-ilka al-hamra, Zaatari emphasizes two separate moments that can be read as queer moments. The first is when the lover picks up a red chewing gum amid the other white pieces of chewing gum from the box and slowly inserts it his mouth with his finger, perhaps suggesting an oral sexual act. As soon as the gum touches the back of his tongue, the video freezes for a slight moment. Furthermore, when the narrator's lover sticks his tongue out after placing the gum on it, the video blurs a bit, and its sequence goes into slow-motion. The second moment is when the narrator asks his lover if he has money on hand, to which the lover responds: "yes" (7:06 min). We see the narrator handing dollar bills to his lover for him to possibly give to the vendor boy, as the lover had earlier inquired "about the cost of the whole box" (5:04 min). In both still moments, the instrumental introduction to Amr Diab's love song accompanies the images, which begin to move again a split-second after the song has begun. The use of slow-motion and video stills are effects that play into queer temporality to interrupt our traditional narrative (Schoonover \& Gault, 2016). These moments literally disturb the flow of time as experienced by the audience.

Furthermore, they refer to the dilation of time in moments of heightened sensuality and emotionality - which is indicated by the juxtaposition of the love song, itself only a fragment. The slowing and freezing of the video 
also transform the banal acts of licking one's finger and exchanging money into sensually erotic acts among the three men - the elongation of the moment creates a space where we may wonder: did the men's hands touch too long? How does lingering on a taste sensualize the act? In sum, Zaatari's use of such visual styles and tactics underlines the eroticism and desires that would normally be go unnoticed.

\section{Hesitations}

The slow and frozen moments in the video can additionally be read as acts of hesitation, which also destabilizes concepts of linear time. We see hesitation everywhere in the narrative, beginning with the narrator's tone. The first instance is between the actors playing the narrator and his lover, discussing whether or not to "sing for him [the vendor]" (1:28 - 1:31 min). The next moment, which seems to escalate the situation, is when the lover is dared to chew the masticated gum first, and refuses, daring the narrator to chew first instead, and asking, "is there no more sugar left?" (2:46 min). The final moment of hesitation comes near the end, when the men are thinking about purchasing the vendor's box - they not only hesitate with whether to buy it or not, they also hesitate to decide who should pay for it (5:04 min).

At another level, Zaatari causes hesitation in the viewer's gaze by use of the frozen moments already discussed. The destabilization and fragmentation of time, as well as the theatricality, cause us to question our understanding of the love story. Furthermore, Zaatari causes hesitation by depicting abject images of the masticated gum pieces. Perhaps the images both repel and fascinate us; we may wish to look away, but also to see more. In Powers of Horror (1982), French psychoanalyst Julia Kristeva explores the concept of abject. She refers to explicit "abject" examples such as the corpse, vomit, excrement, and blood to show how their presence creates a feeling of revulsion and disgust. In her attempt to understand one's repulsion and fascination when thinking about bodily fluids, Kristeva notes, "It is not lack of cleanliness or health that causes abjection but what disturbs identity, system, order" $(1982,4)$. In this sense, the moments where the protagonists are sharing bodily fluids are not only disrupting and threatening the patriarchal structures, they also transgress our sense of cleanliness.

The hesitations, within the video, work to produce a type of broken, slower flow to the narrative. In Sara Ahmed's terms, such a film has a "queer orientation" (2006) because of its non-normative and askew linearity. As argued by Thomas Waugh and Jason Garrison, queer storylines are usually inclined to open-endedness, loss, and displacement narratives, as opposed to generic closure $(2010,89)$. Al-ilka al hamra's queer orientation is one that diverts from the linear and normative storyline. In fact, one may suggest Zaatari experiments with a circular narrative - one that is continuously referenced and restated by the narrator in his flashbacks. This causes a disorientation for the viewer, who simultaneously navigates in-between times (before and after the Civil War) and spaces (the outside alleyway and the studio).

\section{"The Shadow Boy" Figure}


A central character in the video is the vendor, who is referred to as "the shadow boy" by the narrator (8:15 $\mathrm{min}$ ) as he is never fully seen - we only ever catch fragments of his face and body. As portrayed by Zaatari, he seems to be constantly shifting and resisting our gaze, and our attempts to identify him. Additionally, we are offered limited biographical information about his person. He is invisible. We do not know him; we only know of him. Is he a local Lebanese vendor? Is he an undocumented migrant worker from a disadvantaged class? We could suggest that by rendering the young vendor invisible, Zaatari is perhaps seeking to underline the erasure of vulnerable workers, migrants, and refugees working precariously in Lebanon. The young vendor first appears at the beginning of the video as a shadowy figure, standing and loitering at the corner of an unmark street. He is seen acting strangely: he repeatedly, almost compulsively, chews almost every single piece of gum. By consuming his stock of gum, he is destroying his means of profit, which seems illogical. In a time of war, perhaps he wants to taste, for himself, every last granule of sugar within the gums - reveling in and enjoying something before, potentially, his last hour. Thus, Zaatari has constructed a space where a queer act is not only possible, but sensible.

Iranian filmmaker Abbas Kiarostami's Taste of Cherry (1997) also examines a similar experience of a simple pleasure. The film recounts the story of Mr. Baddi, a wealthy middle-aged Iranian man, who drives through Tehran's suburbs searching to hire a man who will agree to bury his body after he dies of suicide. Throughout the film, we never fully understand why Baddi wishes to end his life. In fact, Kiarostami offers little information about the protagonist's personal history and background. All of the potential individuals approached by Baddi decline to partake in his request. However, Baddi finally encounters a Turkish taxidermist named Mr. Baghi, who reluctantly agrees to help him out. During their car ride, Baghi reveals he too had once contemplated suicide by hanging himself from a cherry tree. Moments after his failed suicide attempt, where the tree branch cracked, he felt the soft skin of cherries rubbing against his hands before eating one. It is the taste of the "deliciously sweet cherries," as explained by Baghi, that prevented him from dying. The sweet fruit reminded him of the simple pleasures of life and nature, something he could not leave behind. Near the end of the film, Baghi attempts to dissuade Baddi by asking him, "You want to give up the taste of the cherries?" This sentence is key to the core narrative of the film. Kiarostami seems to suggest that while there is less optimism within an oppressive regime, life is worth living because of its simple pleasures.

A common thread in both videos is the depiction of the protagonists as average people. While the protagonists are seen and heard struggling with their troubling experiences and unresolved issues, their personal histories and backgrounds are purposefully masked by both Zaatari and Kiarostami. This is perhaps done to allow a more complex and imaginative reading of the main characters by the spectators. Visually, the works are similar in the sense that they are for the most part filmed in interior spaces (in a car with open windows overlooking the landscape and in a cloned alleyway recreated in a studio setting). The surroundings of both spaces are blurred.

Interestingly, both films use some type of obscured language which may be read as homosexual pickup lines (Ciment and Goudet 1997). For instance, Baddi approaches the young single men for help and asks them: "if you have money problems, I can help;" in Zaatari's video-letter, the narrator's lover asked the young vendor for money. What this may suggest is that the protagonists are seen as marginal individuals negotiating while 
driving in obscure areas far beyond the strict limits of the city and society. Furthermore, the films deliberately aim to obscure names, faces, and motives from the spectator. In many instances, we can hear voices offscreen; the camera never reveals the actor playing the role. Compared to Kiarostami's Taste of Cherry, Zaatari's Al-ilka al-hamra is not a feature film and does not aspire to be quite as poetic and enigmatic. For example, Kiarostami uses a poetic object (a cherry) to reference life's simple pleasures and the appreciation of nature, whereas Zaatari employs a cheap manufactured plastic object (a chewing gum) that is commonly related to popular culture and consumerism, with an erotic subtext.

\section{The Red Chewing Gum}

In Al-ilka al-hamra's storyline, the red chewing gum is the focal point. Across cultures, the chewing of gum is seen as rude, irreverent, demonstrating coolness, while also conveying sexual associations with sex and the body (Redclift 2004, 2). At first glance the sweet and flavorful flexible material may seem innocent. However, we quickly understand how it alludes to the sexual undertone between the protagonists. Within the video, the gum can be seen as a sensual object explored by the characters - they touch it, place it in their mouths, suck on it, chew it, taste it, spit it, and share it. In this sense, the gum may represent a penis, its red color perhaps signifying an erection, which in some people reddens the tip. While the chewed gum can be associated as an abject object, it remains fascinating and pleasurable for all three characters. In this sense, we may understand their fascination as a queer tactic of appropriation by Zaatari - he has seized the disgust that is used by heteropatriarchy to injure men that do not uphold hegemonic masculinity, and revels in it. This is a classic queer tactic - one remembers the appropriation of derogatory terms by sexual and racial minorities to define and empower themselves. Thus, Zaatari has appropriated a common, non-significant object into a metaphor of queer reading.

When discussing gum as both an object and a metaphor in contemporary art history, one may turn to the well-known artwork S.O.S Starification Object Series (1974-75) by American feminist artist Hannah Wilke. The work constitutes a series of black-and-white photographs of Wilke posing seminude against a neutral backdrop, while occasionally accessorizing with sunglasses, turbans, and ties. She plays, through satire, with the traditional representations of "femininity" by imitating the stance of female models from high-fashion magazines and advertisements. In each photograph, small pieces of pink chewing gum, which she has molded and folded to resemble female genitals (vulvas), are sporadically applied to her seminude body. These visually disruptive shapes may recall the numbered tattoos given to Holocaust victims (which would explain the "star" in the title of the work Starification), while also referencing non-Western rituals of scarification on bodies as a rite of passage (Frueh and Kochheiser 1989; Wacks 1999; Wilke et al. 2006). For Wilke, the gum holds a political message. She writes: "I chose gum because it's the perfect metaphor for the American woman [...]. Chew her up, get what you want out of her, throw her out and pop in a new piece [...]" (qtd. in Berman 1980, 77). This said, Wilke seeks to challenge the male gaze by transforming the vaginalike forms on a desirable female body into repugnant growth-like formations. The gum seems to simultaneously read as erotic, sexy, and unsettling, whereas in Zaatari's work, the gum becomes a central desired and attractive object that could become phallic. 
Some may still find non-heterosexual affection visually repulsive, thus creating an emotional reaction of disgust. As explored by psychologists Todd G. Morrison et al., one may be triggered by bodily moral disgust that happens when people consider that "a sexual practice is taboo and violates a given moral code (e.g., anal intercourse between two men is against God's law)," and sexual disgust that "occurs without reference to taboo and morality (e.g., anal intercourse between two men is disgusting because it involves feces" (2018, 9). In Al-ilka al-hamra, not only can the act of two men being intimate considered "disgusting" by some, the idea of them sharing a chewed-up piece of gum and exchanging fluids becomes more repulsive (or disgustevoking). For example, the nature of chewing (in this case the gum) may trigger reactions of repulsion because it breaks down and transforms the food into viscous substance that is digested and later evacuated from the anus as feces. For researcher William lan Miller, "the mouth and the anus bear an undeniable connection [...] literally connected, each being one end of a tube that runs through the body" $(1997,95)$. For some people, the reference of the anus and its proximity to feces may be associated to contaminations and infections (e.g. hepatitis A and $\mathrm{E}$ coli).

In the video, the chewed gum is shared by the three men; their spit is exchanged from mouth to mouth. Here, one could postulate that their saliva is representative of semen. As previously mentioned, the term "sugar" is used to describe the sweet flavor of the gum. When the gum loses its flavour, the characters dispose of it by spitting it out. The texture and consistency both exhibit gel-like textures and elicit sweet flavour profiles. In one blurry scene, the lover sticks his tongue out, showing a red stain left by the red chewing gum. The stain may suggest that a sexual act (i.e. fellatio) was performed; it could also be read as the sexual consumption of the young man. The fact that the scene is out of focus could imply that the act of non-heterosexual sex is, again, censured, and thus may only exist in the shadows of the cityscape.

As the saliva may be seen as the substitute for semen, Zaatari's aim may be to provoke attraction and repulsion in the audience. This is significant within the context of a heteropatriarchal order which strictly regulates "acceptable" non-disgusting sex because semen is understood to pollute in a number of ways. As elaborated by Miller, semen "has the capacity to feminize and humiliate that which it touches" $(1997,19)$. This is pertinent as it illuminates the particular male disgust for "feminized" men. Here, Zaatari seems to appropriate and revel in disgust as defined by the heterosexist patriarchy. By doing so, he both creates a queer space in which homoerotic acts may exist and challenges his audience to redefine the fixed conceptions that automatically censure and marginalize expressions of male to male desire, intimacy, and sexuality.

The final image that I examine within Al-ilka al-hamra involves that of the flashlight. In the dark alley way, one of the protagonists uses a flashlight to illuminate their path. However, not only does the flashlight shine light on the tight dark road, but onto the body of the vendor as well. Here we can suggest that the flashlight serves two significations. The first is the objectification, fragmentation, and sexualization of the subject, in this case, the vendor. The flashlight only illuminates parts of his body, repeatedly focusing on the mouth - perhaps bringing attention to oral pleasures. The use of strong light to emphasize parts of the body is reminiscent of that used in baroque art. For instance, Caravaggio's paintings dramatically and symbolically highlight with a 
single bright light the wounds and fleshiness of Christ's body. Secondly, the flashlight can be perceived as a tool of the authorities - who represent the heteronormative order - as it searches for and investigates transgressions of hegemonic masculinity, much like in the times when the police would raid gay cruising spots such as saunas or movies theaters.

Throughout the late 1960s until the early 1990s, in Canada and the United States, it was a common practice for the police to locate and regularly raid gay establishments, such as bars, clubs, and bathhouses. As a technique of intimidation, the police would sometimes shine their flashlights into the face and eyes of the patrons with the pretext of checking for intoxication (Janoff 2005; Kinsman and Gentile 2010). Such techniques of shining bright lights onto a suspect's face has been designed by police authorities to regulate and obtain confessions (Godsey 2009). It is reported that in some instances the flashlight itself became a weapon used to beat men up and in some more extreme circumstances sexually assault them (Janoff 2005). It has been documented that medical professionals and police investigators in Turkmenistan have used flashlights, among other tools, during "anal tests" to examine inside the detainee's anus for fissures (Ghoshal 2016). During the raids at Cinema Plaza in Beirut on July 28, 2012, policemen were armed with guns and flashlights to identify the men. While no physical abuse was reported during these "crackdowns," the police were verbally abusive towards the arrested men (Chahine 2008). What happens behind closed doors during the interrogation between the police investigators, medical professionals, and accused men are not always well-documented. Many of these men are hesitant to discuss their experience publicly, for fear of being harassed, threatened, and outed by police, or simply feeling ashamed (Chahine 2008).

Recently, the Search for Common Ground (SFGG) - a non-governmental organization in Lebanon focusing on conflict transformation - and the Internal Security Forces (ISF) have implemented new police campaigns and modes of surveillance that aim to appease the general public in regard to larger "security threats" facing the country, such as "[...] refugee influx, unemployment, homelessness, sex work, poverty as well as a selective attitudes on proper gender and sexual behaviors [...]" (Saleh and Qubaia 2015). The SFCG and ISF's growing policing and surveillance of "proper" gender and sexual behaviors has led authorities to define, by themselves, acts and individuals considered threatening or "deviant" (Saleh and Qubaia 2015). Any individual deemed "doubtful" or "suspected of homosexuality," for example, can be arrested and detained by authorities under the pretext of representing a security threat (Chahine 2008; Saleh and Qubaia 2015). As argued by philosopher Michel Foucault (1977), such surveillance of public and private spaces is put into place to expose "deviant" sexual practices that have fallen outside of the normative regime. Thus, non-normative individuals and behaviours are constantly undergoing scrutiny and state intervention to be controlled with disciplinary strategies (Foucault 1977). As queer theorist Jasbir Puar points out, "the daily monitoring activity is linked not only to fears of being exposed but also to desires to surveil others and fears generated by exposure to others" (2017, 163 n.14). In other words, while modern "regimes of surveillance" shape exemplary subjects, they also enforce subjects to discipline themselves while keeping tabs on others (Puar 2007). While the video camera overexposes the faces and bodies of each protagonist, it continuously seeks, but fails, to automatically focus, thus creating a blurred, grainy, and shadowy image of the protagonists. 
Al-ilka al-hamra ends in a peculiar way. On the wall of a studio setting, we see a low-quality projection of Hamra Street playing, while the narrator speaks for the last time: "[...] do you remember him? He sends you his regards I hope you remember him" (10:04 - 10:06 min). This puzzling moment in the video creates an open-ended narrative that triggers even more questions about the young men's queer relationship and experience. Do they still see each other? If so, is it in a casual way on the street or otherwise? One can think that perhaps the exchange of money in the earlier scenes could suggest that the young vendor was a sex worker. Does the narrator still have contact with the vendor? Are they lovers? The strength in the video lies in the ability to create ephemeral, fractured, and uncertain moments, which can be termed as queer microexperiences. The video unfollows the logical and conventional production of what seems to be a circular narrative. While a Western viewer may suggest that the characters fall into the stereotype of the gay men meeting up clandestinely in dark alleys, we must be reminded that they are in search of forging their own spaces of encounter.

\section{Conclusion}

Within Lebanon's contemporary sociocultural context, where "unnatural sex acts" and the intersections with migration, sex work, and poverty are highly restricted, one can suggest that the shinning bright light in the participants' faces, in Al-ilka al-hamra, is a reminder that they are constantly under scrutiny. While the men do not openly identify as gay, their acts are not heteronormative. Thus, they are taking many risks, which jeopardizes both their physical safety and social standing, especially that the imagery points to at least some of them being workers and/or migrants. The video can also be indicative of danger associated with war, a lockdown, a sense of urgency - which paradoxically facilitates the men's willingness to disregard the rules and pursue their pleasure. In addition to the techniques employed in the video, the staging in a studio setting attempts to recreate multiple dimensions of a queer experience and destabilizes concepts of linear time, natural space, and normative values. The video can be described, to a degree, as queer, in terms of its staging of sexuality, non-heteronormativity, and depiction of perverse pleasures that would be censored if the General Security knew how to "read" the codes. 


\section{References}

Ahmed, Sarah. 2006. Queer Phenomenology: Orientations, Objects, Others. Durham and London: Duke University Press.

Al-Adaileh, Bilal A. 2012. "The Connotations of Arabic Colour Terms." Linguistica Online (13):35-52.

Balaa, Luma. 2019. "Framed: The Door Swings Both Ways in the Lebanese Movie Caramel Directed by Nadine Labaki, Produced by Anne-Dominique Toussaint; Written by Nadine Lebaki, Rodney El Haddad, Jihad Hoiely. Sunnyland Films, Lebanon, May 2007. Running time 96 minutes." Journal of International Women's Studies 20 (7): 430-447.

Berman, Avis. October 1980. "A Decade of Progress, But Could a Female Chardin Make a Living Today." Art News 79 (8): 73-79.

Chahine, Pascal. 2008. "(Re)Constructing Beirut: Helem and 'Local' Homosexualities." Institute of Islamic Studies, McGill University.

Ciment, Michel, and Stéphane Goudet. February 1997. "Entretien avec Abbas Kiarostami: Une approche existentialiste de la vie." Positif 442: 83-89.

Edelman, Lee. 2004. No Future: Queer Theory and the Death Drive. Durham and London: Duke University Press.

El Chamaa, Mohamad. March 18, 2016. "The Making of Hamra Street - Part One." In Outlook. Beirut.

Fitzpatrick, Andrea D. 2015. "Veiled Iranian Identities in the Photographic Art of Sadegh Tirafkan." Men in Crisis / der Mann in Der Krise? Eds. Söll, Änne and Gerald Schröder. Berlin: Böhlau-Verlag: 182-98.

Foucault, Michel. 1977. Discipline and Punish. Harmondsworth: Penguin.

Frueh, Joanna, and Thomas H. Kochheiser. 1989. Hannah Wilke: A Retrospective, exhibition catalogue, Gallery 210. Missouri: University of Missouri-St Louis.

Ghoshal, Neela. 2016. "Dignity Debased: Forced Anal Examinations in Homosexuality Prosecutions." LGBT Rights Program at Human Rights Watch accessed July 23, 2017.

Godsey, Mark A. 2009. "Shining the Bright Light on Police Interrogation in America." Ohio State Journal of Criminal Law 6 (711): 711-735.

Halberstam, Jack. 2005. In a Queer Time and Place: Transgender Bodies, Subcultural Lives. New York: New York University Press.

---. 2011. "Shadow Feminisms: Queer Negativity and Radical Passivity." In The Queer Art of Failure, 123146. Durham and London: Duke University Press.

Hall, Donald. 2003. Queer Theories. London: Red Globe Press.

Halperin, David M. 2007. What Do Gay Men Want?: An Essay on Sex, Risk, and Subjectivity. Ann Arbor: University of Michigan Press.

Harper, Philip Brian, Francis White, and Margaret Cerullo. 1990. "Multi/Queer/Culture." Radical America 24 (4): 27-37.

Hasan, Amna A., Nabiha Mehdi Al-Sammerai, and Fakhrul Adabi Bin Abdul Kadir. 2011. "How Colours are Semantically Construed in the Arabic and English Culture: A Comparative Study." English Language Teaching 4 (3): 206-213.

Hassan, Omar. 2010. "Real Queer Arabs: The Tension between Colonialism and Homosexuality in Egyptian Cinema." Film International 8 (43): 18-24. 
Honig, Bonnie. 2013. Antigone Interrupted. Cambridge, U.K.: Cambridge University Press.

Houghton, Mifflin. 2007. The American Heritage Dictionary of the English Language. Houghton Mifflin Company.

Jagose, Annamarie. 1996. Queer Theory: An Introduction. Carlton: Melbourne University Press.

Janoff, Douglas Victor. 2005. Pink Blood: Homophobic Violence in Canada. Toronto: University of Toronto Press.

Kiarostami, Abbas. 1997. Taste of Cherry. Iran.

Kinsman, Gary, and Patrizia Gentile. 2010. The Canadian War on Queers: National Security as Sexual Regulation. Vancouver and Toronto: UBC Press.

Kristeva, Julia. 1982. Powers of Horror: An Essay on Abjection. Translated by Leon S. Roudiez. New York: Columbia University Press.

Marks, Laura U. 2000. The Skin of Film: Intercultural Cinema, Embodiment, and the Senses. Durham: Duke University Press.

Merabet, Sofian. 2014. Queer Beirut. Austin: University of Texas Press.

Miller, William lan. 1997. The Anatomy of Disgust. Cambridge, Mass. \& London: Harvard University Press.

Morrison, Todd G., Mark J. Kiss, CJ Bishop, and Melanie A. Morrison. 2018. "We're Disgusted with Queers, not Fearful of Them': The Interrelationships Among Disgust, Gay Men's Sexual Behavior, and Homonegativity." Journal of Homosexuality $66 \quad$ (7): 1014-1033. https://doi.org/https://doi.org/10.1080/00918369.2018.1490576.

Muñoz, José Esteban. 2009. Cruising Utopia: The Then and There of Queer Futurity. New York: New York University Press.

Puar, Jasbir. 2007. Terrorist Assemblages: Homonationalism in Queer Times. Durham: Duke University Press.

Puar, Jasbir. 2017. The Right to Maim: Debility, Capacity, Disability. Durham and London: Duke University Press.

Ruvalcaba Dominguez, Héctor. 2016. Translating the Queer: Body Politics and Transnational Conversations. London: Zed Books.

Saghieh, Nizar, Rana Saghieh, and Nayla Geagea. 2010. "Censorship in Lebanon: Law and Practice." Heinrich Böll Foundation. Retrieved https://lb.boell.org/sites/default/files/2010. censorship_in_lebanon-_law_practice_en.pdf.

Saleh, Ahmad J., and Adriana A. Qubaia. 2015. "Transwomen's Navigation of Arrest and Detention in Beirut: A Study Case." Civil Society Knowledge Centre, Lebanon Support. Retrieved from http://civilsocietycentre.org/pdf-generate/29155.

Schoonover, Karl, and Rosalind Galt. 2016. Queer Cinema in the World. Durham and London: Duke University Press.

Sedgwick, Eve Kosofsky. 2003. Touching Felling. Affect, Pedagogy, Performativity. Durham and London: Duke University Press.

Sharifi Isaloo, Amin. 2017. Power, Legitimacy and the Public Sphere: The Iran Ta'ziyed Theatre Ritual. New York: Routledge.

Wacks, Debra. Summer 1999. “Naked Truths: Hannah Wilke in Copenhagen.” Art Journal 58 (2): 104-106. 
Warner, Michael. 1993. Fear of a Queer Planet: Queer Politics and Social Theory. Minneapolis: University of Minnesota Press.

Waugh, Thomas, and Jason Garrison. 2010. Montreal Main: A Queer Film Classic. Vancouver: Arsenal Pulp Press.

Wilke, Hannah, Laura Fernández Orgaz, Saundra Goldman, and Juan Aliaga Vincent, eds. 2006. Hannah Wilke: Exchange Values. Victoria-Gasteiz: Atrium, Centro-Museo Vasco de Arte Contemporáneo.

William Steffler, Alva. 2002. Symbols of the Christian Faith. Grand Rapids, Michigan and Cambridge, U.K.: William B. Eerdmans Publishing Company.

Zaatari, Akram. 2001. Red Chewing Gum. Lebanon. 